\title{
QUANTUM PHYSICS BASED ANALYTICAL MODELING OF DRAIN CURRENT OF SINGLE ELECTRON TRANSISTOR WITH ISLAND MADE OF ZIGZAG-TUNGSTEN DISULFIDE NANORIBBON
}

\author{
(D)Milan K. Bera \\ Assistant Professor, Department of Physics, Maharishi Markandeshwar (Deemed to be University) \\ Mullana, Ambala, Haryana, India \\ Corresponding Author: m.k.bera@mmumullana.org \\ Received September 23, 2020; accepted November 4, 2020
}

\begin{abstract}
Among many emerging nanoelectronic devices, single-electron transistor (SET) is one of the frontier device architectures that can offer high operating speed at an ultra-low power consumption. It exploits controlled electron tunneling to amplify current and retains its scalability even on an atomic scale. A new island based SET device architecture is proposed which is made of monolayer tungsten disulfide nanoribbon $\left(\mathrm{WS}_{2} \mathrm{NR}\right.$ ) in zigzag pattern. The quantum physics based analytical model is developed in order to investigate the tunneling drain current flowing through the proposed $\mathrm{WS}_{2}$ NR SET. It has been observed from the simulation study that the device current did not struggle in the coulomb blockade region whereas outside this region drain current value gradually decreases for longer nanoribbon likely due to formation of wider potential well in the island regime which helps to drop the rate of tunneling electrons.

KEYWORDS: Coulomb blockade, Nanoribbon, Single electron transistor, Tungsten Disulfide, Tunneling current
\end{abstract}

In digital integrated circuits, transistors operate in switching mode to change the desired logic voltage levels either 0 or 1. Downscaling of individual device size has been the driving force for improving the performance of ultra-largescale integrated circuits (ULSIs) [1-2]. In this regard, Metal-oxides semiconductor field-effect transistors (MOSFETs) have been the most successful electronic devices for ULSI application. However, MOSFETs are now facing serious challenges to continue downscaling owing to its fundamental physical limitations in the deep-submicron regime. In this respect, single-electron transistors (SETs) are promising as emerging nanoscaled devices since these devices are scalable even on an atomic scale. Meanwhile, SET are able to control individual movement of electron. Therefore, if SETs are implemented in ULSI design, it will have the attributes of extremely high integration and low power consumption [2].

SET demonstrates unique switching characteristics utilizing quantum mechanically governed coulomb blockade and single electron tunneling phenomena mediated via island regime [3-5]. Furthermore, room temperature operation is the key for practical implementation of SET in ULSI. Although, the first experimentally demonstrated SET in 1987 was operable only at ultra-low temperature ranges (1.1-4.2 K), however, it was improved later on for room temperature operation by adopting silicon as island [6-7]. As soon as it was realized that the band structure and electrical properties of the island materials are the key for room-temperature operation, SET made of new island materials such as twodimensional (2D) graphene have been demonstrated recently [8].

In this context, lower dimensional semiconductors particularly transition metal dichalcogenides (TMDs), as for example, $\mathrm{MoS}_{2}, \mathrm{MoSe}_{2}, \mathrm{WSe}_{2}, \mathrm{WS}_{2}, \mathrm{WS}_{2}$ etc. possess additional benefits due to atomically smooth and dangling-bond free surface, charge carrier scattering or even thickness (hence bandgap) variation, thus, guarantees robust device performances at room temperature [9-10].

Therefore, in this study, a new island material made of monolayer tungsten disulfide $\left(\mathrm{WS}_{2}\right)$ nanoribbon in zigzag pattern is proposed in SET design. Quantum physics based analytical modelling of tunneling current has been developed in order to accurately predict the electrical performances of SET at room temperature via numerical simulations coded in Matlab and Mathematica.

\section{MODELING AND SIMULATION OF SINGLE ELECTRON TRANSISTOR WITH ISLAND MADE OF MONOLAYER WS2-NANORIBBON}

Fundamentals of SET operation with island

Single-electron transistor is governed by quantum mechanical tunneling effect. A single electron transistor is simply constructed with an island sandwiched between two tunneling junctions formed at source and drain side. It is also connected through a capacitor into the gate electrode as shown in Figure 1a below. SET can also be seen as a confined box that has two separate junctions for the entrance and exit of a single electron. Now, according to the fundamentals of quantum mechanics, the electrical conduction of any tunnel junction purely depends on how effectively the barrier transmits the electronic waves. The electric current flow decreases exponentially with the barrier thickness.

As soon as an electron tunnels through the junction, the tunnel capacitance is charged with a single electronic charge and as a result tiny amount of potential is built up. This additional potential might be sufficient to prevent another electron to tunnel through the junction. In this scenario, the resistance of the tunnel junction rises consistently, thereby coulomb blockade condition arises which ultimately stops the flowing of current. When external bias is applied, the coulomb blockade situation overcomes then electrons resume tunneling one by one from source to the island, hence, adding excess 
electrons to the island (see Figure 1b). A similar tunneling process will also occur from the island to the drain. Eventually, single electron transistor monitors the flow of electronic charge between source and drain with the assistance of gate electrode.

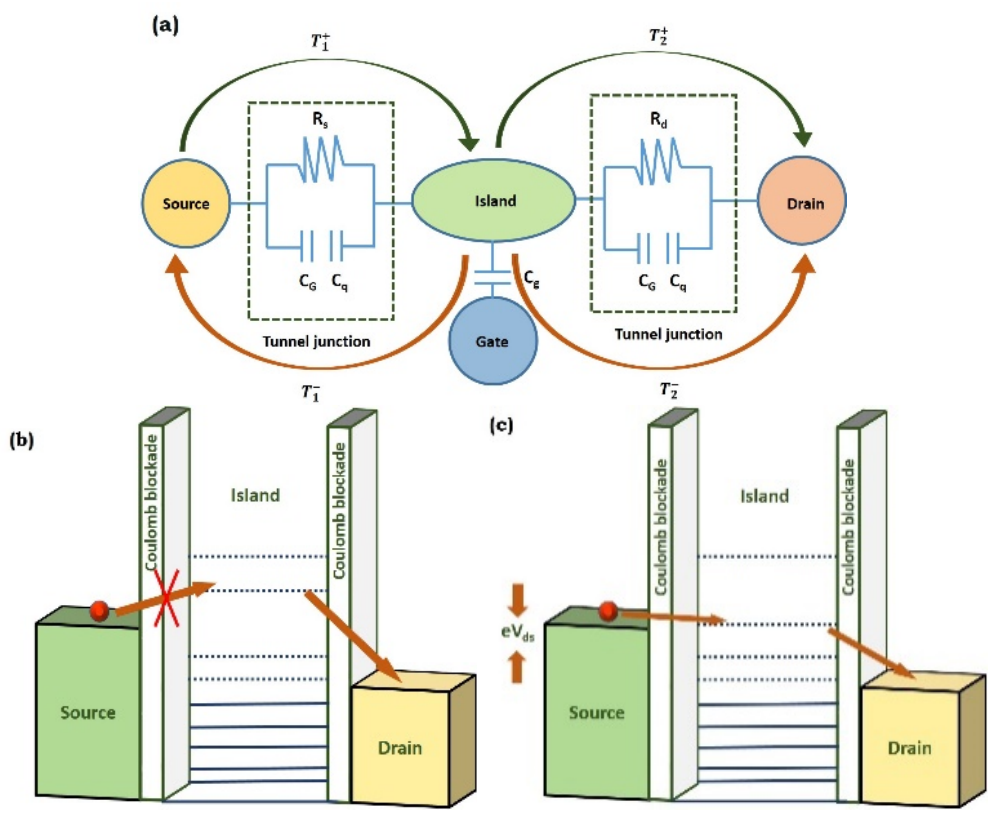

Figure 1. Schematic structure with equivalent circuit of single electron transistor, (b) Coulomb-blockade condition with zero current, (c) adequate drain-source bias voltage will assist to transfer of an electron across the barrier.

\section{Basic structure of zigzag-WS 2 -nanoribbon}

Monolayer $\mathrm{WS}_{2}$ nanoribbon can be patterned into two different forms, one in armchair and other in zig-zag shape. Zig-zag patterned $\mathrm{WS}_{2}$ nanoribbon is composed of an inner layer of $\mathrm{W}$ metal atoms orderly positioned in triangular lattice. It is sandwiched between two layers of chalcogen sulfide (S) atoms positioned on the triangular lattice of interchanging hollow sites in a triangular prismatic style [11].

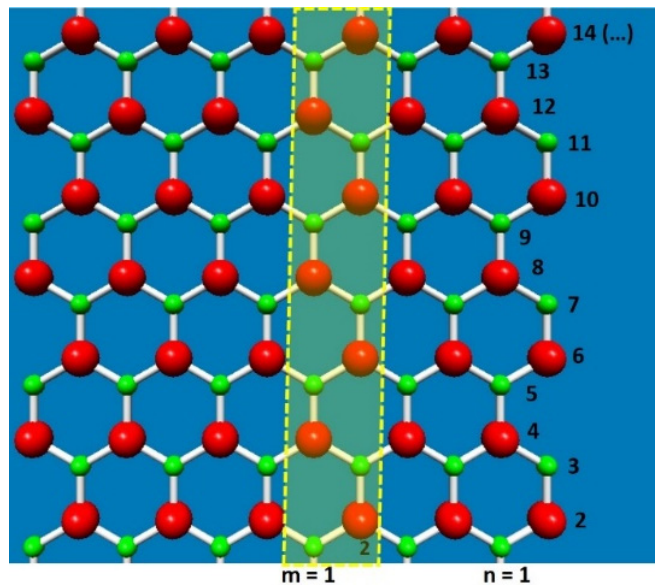

Figure 2. Top view of lattice structure of monolayer $\mathrm{WS}_{2}$ in zig-zag pattern. Red and green spheres denote the metal (W) and chalcogenide $(\mathrm{S})$ atoms, respectively. The shaded area indicates the unit cell in zig-zag pattern. The position of lattice sites are demarcated by coordinates $(m, n)$.

The S-W-S layers are bonded by weak van der Waals forces. A schematic is shown in Figure 2. The unit cell described as $(\mathrm{m}, \mathrm{n})$ indices is illustrated by shaded rectangular area.

\section{Modeling of tunneling current flowing through the proposed WS 2 NR SET}

As per discussion in earlier section, a single electron transistor is made of source, gate, and drain electrodes along with an island which is located between source and drain but is not actually connected to them. It is shown schematically in Figure 3. The basic operation of SET is controlled by quantum tunneling of electrons to amplify the current values. As depicted in Figure 3, SET can be divided into three regions, corresponding to source, island and drain parts. The energy as a function of position alongside SET is also demonstrated. The proposed $\mathrm{WS}_{2} \mathrm{NR}$ island of length $\mathrm{L}$ can be assumed as a quantum well whose potential profile along the island is shown in Figure 3. 
Now, following the fundamentals of quantum mechanics in solving Schrödinger equations, the electronic wave functions in various regions can be established as follows [03, 12]:

$$
\begin{gathered}
\operatorname{Reg}-I: \psi_{I}=A e^{k_{I} x}+B e^{-k_{I} x} \text { but } \psi_{I}^{*} \psi_{I} \rightarrow 0 \text { when } x \rightarrow-\infty, \text { hence, } B=0 \\
\operatorname{Reg}-I I: \psi_{I I}=C e^{i k_{I I} x}+D e^{-i k_{I I} x} \\
\operatorname{Reg}-I I I: \psi_{I I I}=E e^{k_{I I I} x}+F e^{-k_{I I I} x} \text { but } \psi_{I I I}^{*} \psi_{I I I} \rightarrow 0 \text { when } x \rightarrow+\infty, \text { hence, } \varepsilon=0
\end{gathered}
$$

where $k_{I}=k_{I I I}=\frac{\sqrt{2 m_{e}^{*} \varepsilon}}{\hbar}$ and $k_{I I}=\frac{\sqrt{2 m_{e}^{*}\left(v_{0}-\varepsilon\right)}}{\hbar}, \varepsilon(<0)$ is the energy of electron, $v_{0}$ is potential well $m_{e}^{*}$ is the effective mass of $\mathrm{WS}_{2} \mathrm{NR}, \hbar$ is the reduced Planck's constant. The negative value indicates bound electronic energy states.

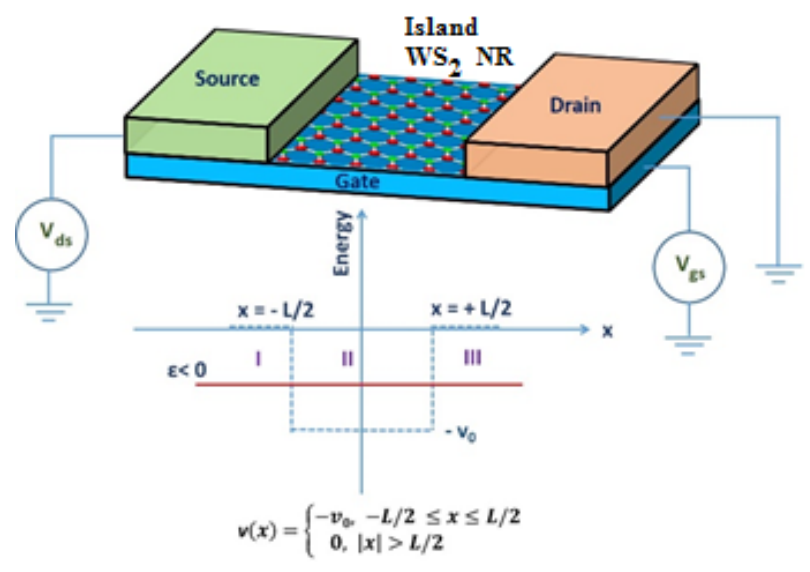

Figure 3. Schematic of proposed single electron transistor with island made of $\mathrm{WS}_{2}$ nanoribbon. The biasing points at different electrodes as well as potential profile along the device are also shown.

Now, as per boundary conditions, the wave functions and its first derivatives must be continuous for the neighbouring regions at $\mathrm{x}=-\mathrm{L} / 2$ and $\mathrm{x}=+\mathrm{L} / 2$. Therefore, applying boundary conditions the above equations becomes:

$$
\begin{gathered}
A e^{\frac{-k_{I} L}{2}}=C e^{-\frac{i k_{I I} L}{2}}+D e^{\frac{i k_{I I} L}{2}} \text { at } x=-L / 2, \quad \psi_{I}=\psi_{I I} \\
A k_{I} e^{\frac{-k_{I} L}{2}}=C i k_{I I} e^{-\frac{i k_{I I} L}{2}}-D i k_{I I} e^{\frac{i k_{I I} L}{2}} \text { at } x=-L / 2, \quad \frac{d \psi_{I}}{d x}=\frac{d \psi_{I I}}{d x} \\
C e^{\frac{i k_{I I} L}{2}}+D e^{\frac{-i k_{I I} L}{2}}=F e^{\frac{-k_{I I I} L}{2}} \text { at } x=+L / 2, \quad \psi_{I I}=\psi_{I I I} \\
C i k_{I I} e^{\frac{i k_{I I} L}{2}}-D i k_{I I} e^{\frac{-i k_{I I} L}{2}}=-F k_{I I I} e^{\frac{-k_{I I I} L}{2}} \text { at } x=+L / 2, \quad \frac{d \psi_{I I}}{d x}=\frac{d \psi_{I I I}}{d x}
\end{gathered}
$$

Next, the electron transmission coefficients in $\mathrm{WS}_{2}$ NR SET can be calculated as follows:

$$
T_{Q W S N R}(\varepsilon)=\frac{\left(1+k_{I}^{2}\right)^{2} k_{I I}^{2}}{\left(\cos \left(L k_{I I}\right)\left(-1+k_{I}^{2}\right) k_{I I}-\sin \left(L k_{I I}\right) k_{I}\left(1+k_{I I}^{2}\right)\right)^{2}}
$$

The calculation details of the aforementioned equations can be found from Appendix.

Finally, the quantum current flowing through $\mathrm{WS}_{2}$ NR SET can be easily estimated using Landauer formulae [03] as:

$$
I_{Q W S N R}=\frac{2 e}{\hbar} \int \rho(n) T_{Q W S N R}(\varepsilon)\left(f_{S \rightarrow D}(\varepsilon)-f_{D \rightarrow S}(\varepsilon)\right) d \varepsilon
$$

where $\mathrm{e}$ is the electronic charge, $\rho(n)$ is the electron density, $f(E)=\frac{1}{\left(1+e^{\frac{\left(\varepsilon-\varepsilon_{f}\right)}{k_{B} T}}\right)}$ is the Fermi-Dirac distribution

function, $\varepsilon_{f}$ is the Fermi energy level, $k_{B}$ is the Boltzmann constant and $\mathrm{T}$ is the temperature.

RESULTS AND DISCUSSION

The electrical characteristics of proposed $\mathrm{WS}_{2}$ NR SET related to variation in nanoribbon length have been investigated. The simulation results are shown in Figure 4.

It is noteworthy that changes in $\mathrm{WS}_{2}$ nanoribbon length does not have significant influences in the coulomb blockade region (i.e. nearby zero voltage). It can be farther evident from Figure 5 as the current value near zero bias does not struggle rather increases almost linearly. However, it has a direct impact on the SET current values particularly for applied bias $\left(V_{d s}\right)$ outside the coulomb blockade regime. Meanwhile, the drain current, $I_{d s}$ reduces moderately when nanoribbon lengths are varied from $\sim 0.546 \mathrm{~nm}$ to $\sim 2.002 \mathrm{~nm}$. The physical phenomena of these behaviours could be interpreted as a consequence of formation of longer potential well in the island owing to increase in nanoribbon length. 
Because of wider potential well formation between source-drain, the tunneling of electrons decreases, hence, the value of current drops significantly. The influence of operating temperatures on SET current flow have also been investigated. The temperature variation in $I_{d s} v s$. $V_{d s}$ characteristics of $\mathrm{WS}_{2} \mathrm{NR}$ SET is shown in Figure 6 . It can be easily seen from the figure that as temperature rises the tunneling current value increases mainly due to temperature dependent electron occupancy as per Fermi-Dirac distribution such that more electrons are available for tunneling. In addition, carrier freez-out effect may also affect the flow of current at lower temperature particularly at 4K [13].

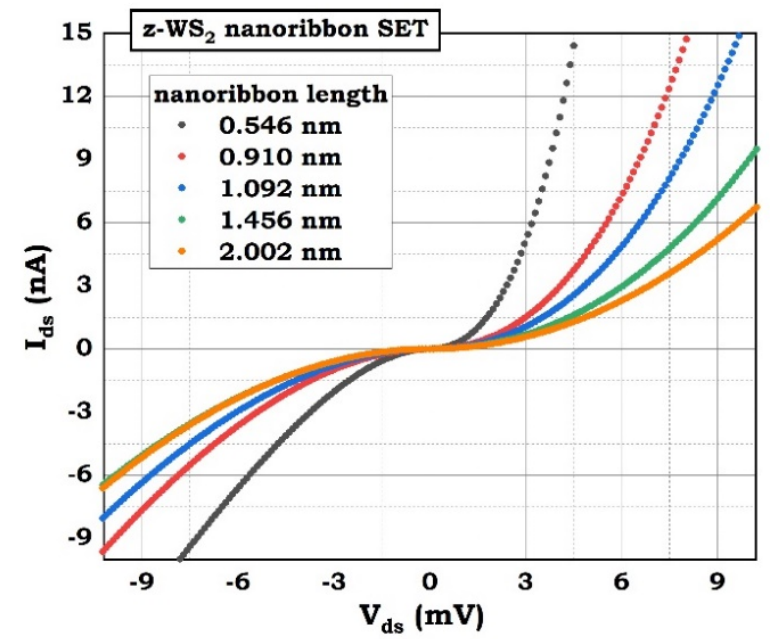

Figure 4. The simulated output characteristics $\left(I_{d s} \mathrm{vs} V_{d s}\right)$ of proposed zigzag-WS $\mathrm{S}_{2}$ NR SET with various nanoribbon length but keeping gate voltage constant at $1 \mathrm{mV}$.

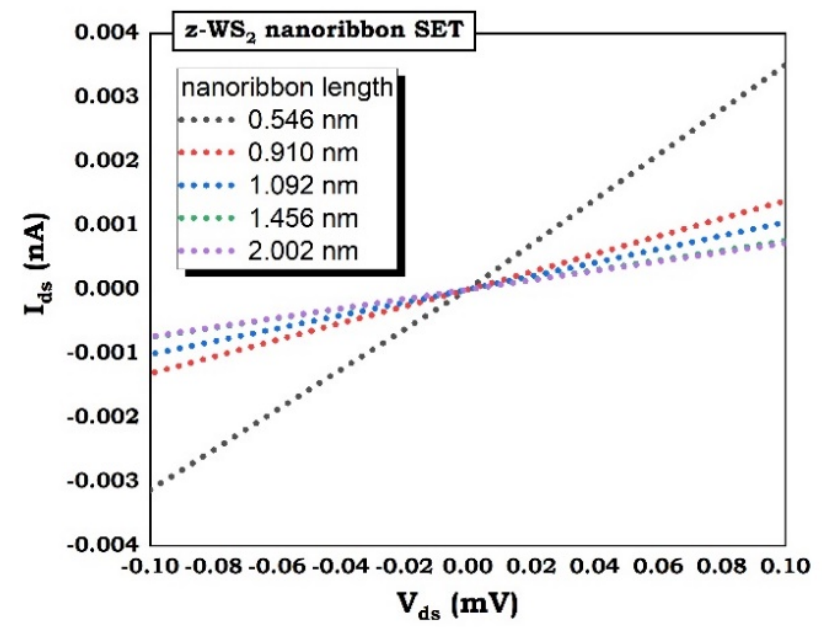

Figure 5. The simulated $I_{d s}$ vs $V_{d s}$ characteristics of zigzag-WS 2 NR SET with varying island length but keeping gate voltage constant at $1 \mathrm{mV}$.

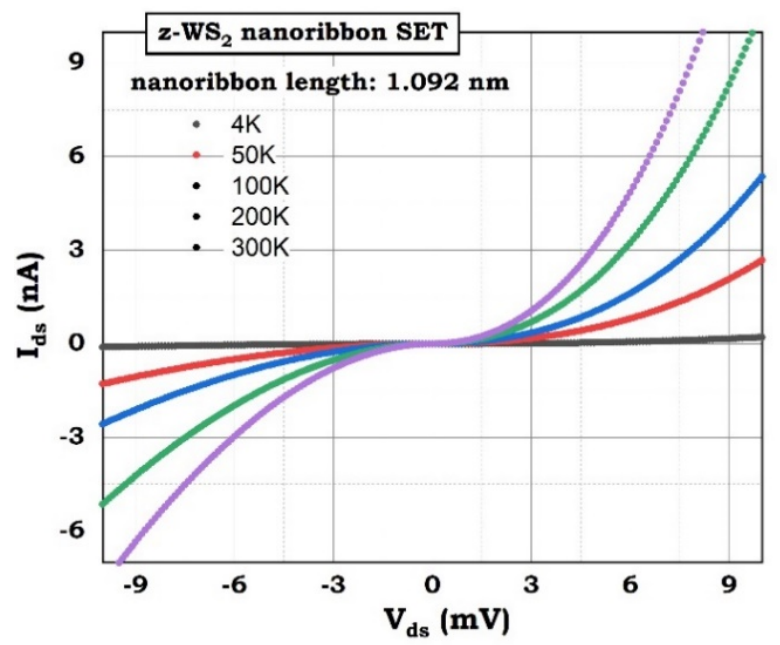

Figure 6. The output characteristics $\left(I_{d s} v s V_{d s}\right)$ of armchair-WS 2 nanoribbon SET at room temperature (300 K) with varying gate voltage in the range of $1-9 \mathrm{mV}$. 
On the other hand, in order to evaluate the gate controllability of the proposed single electron transistor, the simulations were performed on $1.341 \mathrm{~nm}$ long zigzag- $\mathrm{WS}_{2}$ nanoribbon with applied gate voltage varies from $1-9 \mathrm{mV}$ as can be seen from Figures 7.

Again, it can be noticed that there is no significant influence of coulomb blockade during applied gate bias, rather normal device characteristics have been observed.

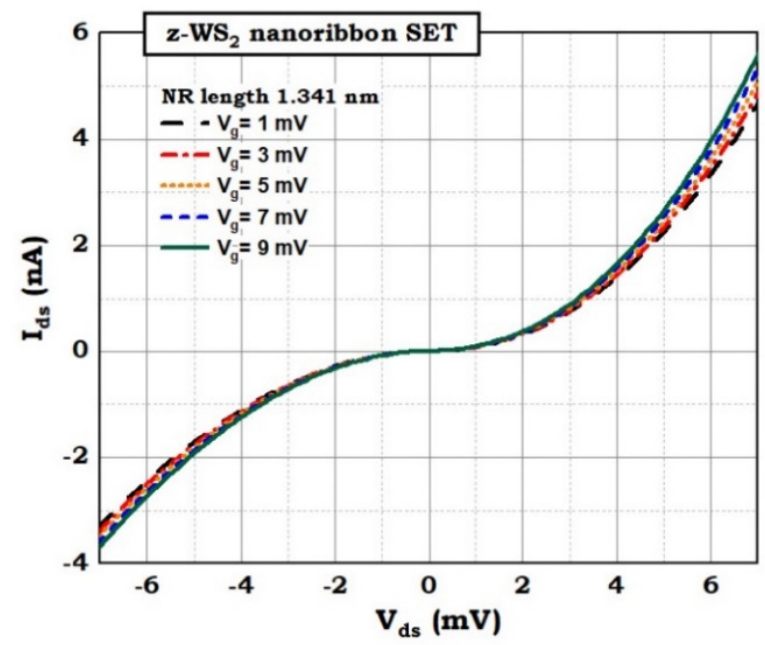

Figure 7. The gate control on the output characteristics $\left(I_{d s} v s V_{d s}\right)$ of single electron transistor with $\mathrm{WS}_{2}$ nanoribbon in zigzag pattern is shown.

\section{CONCLUSIONS}

In the present study, a new island material based on monolayer tungsten disulphide $\left(\mathrm{WS}_{2}\right)$ nanoribbon is proposed to design single electron transistor. Quantum physics based analytical model is developed to simulate the quantum current behaviour of proposed single electron transistor at room temperature. It has been observed that the variation of $\mathrm{WS}_{2}$ nanoribbon length either does not have any significant influence on the coulomb blockade region. Instead, the values of SET current decreases slowly just outside of the coulomb blockade region presumably due to formation of longer potential well in the island, whereby deteriorating the rate of electron tunneling. In addition, variation in operating temperature from 4-300 K drastically improve the tunneling current mainly due to increase in electron occupancy so that more electrons can tunnel through. On the other hand, the gate controllability have also been investigated which exhibits reasonable device performances at room temperature without any trouble of coulomb blockade. Therefore, the proposed single electron transistor utilizing $\mathrm{WS}_{2}$ nanoribbon in zigzag pattern as an island material might be potentially useful by embedding and integrating into advanced ULSI circuit design.

\section{APPENDICES}

Solution of Schrödinger equations with boundary conditions

Applying fundamentals of quantum mechanics, Schrödinger equations in all the regions of $\mathrm{WS}_{2} \mathrm{NR}$ SET can be established as follows [12]:

$$
\begin{aligned}
& \operatorname{Reg}-I:=\frac{-\hbar^{2}}{2 m_{e}^{*}} \frac{d^{2} \psi_{I}}{d x^{2}}=\varepsilon \psi_{I}(\text { where } \varepsilon<0 \& v(x)=0) \\
& \operatorname{Reg}-I I:=\frac{-\hbar^{2}}{2 m_{e}^{*}} \frac{d^{2} \psi_{I I}}{d x^{2}}+v(x) \psi_{I I}=E \psi_{I I}\left(\text { where } \varepsilon<0 \& v(x)=-v_{0}\right) \\
& \operatorname{Reg}-I I I:=\frac{-\hbar^{2}}{2 m_{e}^{*}} \frac{d^{2} \psi_{I I}}{d x^{2}}=E \psi_{I I I}(\text { where } \varepsilon<0 \& v(x)=0)
\end{aligned}
$$

The general solution of Schrödinger equation established in region-I (i.e. source side of SET) can be obtained as follows:

$$
\operatorname{Reg}-I: \psi_{I}=A e^{k_{I} x}+B e^{-k_{I} x}
$$

But according to basic postulates in quantum mechanics, the wave functions must be finite, continuous and single valued to form a wave packet, however, when $x \rightarrow-\infty, \psi_{I}^{*} \psi_{I} \rightarrow \infty$ that is the probability of finding the electron will be infinity, therefore, in order to have finite probability, $\psi_{I}^{*} \psi_{I} \rightarrow 0$ at $x \rightarrow-\infty$, which requires to set $\mathrm{B}=0$.

Meanwhile, at region-II, (i.e. island side of SET), the solution becomes:

$$
\operatorname{Reg}-I I: \psi_{I I}=C e^{i k_{I I} x}+D e^{-i k_{I I} x}
$$



follows:

Similarly, at region-III (i.e. drain side of SET), the solution of the Schrödinger equation can be easily obtained as

$$
R e g-I I I: \psi_{I I I}=E e^{k_{I I I} x}+F e^{-k_{I I} x}
$$

Again, $\psi_{I I I}^{*} \psi_{I I I} \rightarrow+\infty$ when $x \rightarrow+\infty$, hence, in order to have a finite probability of finding electrons in region-III, $F$ must be zero. In the above equations, $k_{I}=k_{I I I}=\frac{\sqrt{2 m_{e}^{*} \varepsilon}}{\hbar}$ and $k_{I I}=\frac{\sqrt{2 m_{e}^{*}\left(v_{0}-\varepsilon\right)}}{\hbar}$, where $\varepsilon(<0)$ is the energy of electron, $\mathrm{v}_{0}$ is potential well $m_{e}^{*}$ is the effective mass of $\mathrm{WS}_{2} \mathrm{NR}, \hbar=\frac{h}{2 \pi}$ is the reduced Planck's constant.

Nevertheless, the wave functions must be continuous for any quantum mechanical system, thus, boundary conditions play important roles to unite the otherwise separated waves at the boundary region. Following boundary conditions, the wave functions and its first order derivatives must be continuous at the boundary of the neighbouring region which yields following equations:

$$
\begin{gathered}
A e^{-k_{I} L / 2}=C e^{-i k_{I I} L / 2}+D e^{i k_{I I} L / 2}\left(\text { at } x=-L / 2, \psi_{I}=\psi_{I I}\right) \\
A k_{1} e^{-k_{I} L / 2}=C i k_{I I} e^{-i k_{I I} L / 2}-D i k_{I I} e^{i k_{I I} L / 2}\left(\text { at } x=-L / 2, \quad \frac{d \psi_{I}}{d x}=\frac{d \psi_{I I}}{d x}\right) \\
C e^{i k_{I I} L / 2}+D e^{-i k_{I I} L / 2}=F e^{-k_{I I I} L / 2}\left(\text { at } x=+L / 2, \psi_{I I}=\psi_{I I I}\right) \\
C i k_{I I} e^{i k_{I I} L / 2}-D i k_{I I} e^{\frac{-i k_{I I} L}{2}}=-F k_{I I I} e^{\frac{-k_{I I I} L}{2}}\left(\text { at } x=+L / 2, \quad \frac{d \psi_{I I}}{d x}=\frac{d \psi_{I I I}}{d x}\right)
\end{gathered}
$$

\section{Calculation of transmission coefficient}

Now, the coefficients of the abovementioned equations from 7-10 can be obtained utilizing transfer matrix method $[3,12]$. From the $\mathrm{x}=-\mathrm{L} / 2$ boundary condition, equations $7 \& 8$ can be written in matrix form as:

$$
\begin{aligned}
& M_{I}\left(\begin{array}{l}
A \\
B
\end{array}\right)=M_{I I}\left(\begin{array}{l}
C \\
D
\end{array}\right) \\
\therefore & \left(\begin{array}{l}
A \\
B
\end{array}\right)=M^{I}\left(\begin{array}{l}
C \\
D
\end{array}\right) \text {, where } M^{I}=M_{I}^{-1} M_{I I}
\end{aligned}
$$

where $M_{I}=\left(\begin{array}{cc}e^{-\frac{L k_{I}}{2}} & 0 \\ k_{I} e^{-\frac{L k_{I}}{2}} & 0\end{array}\right)$ and $M_{I I}=\left(\begin{array}{cc}e^{-\frac{i L k_{I I}}{2}} & e^{\frac{i L k_{I I}}{2}} \\ i k_{I I} e^{-\frac{i L k_{I I}}{2}} & -i k_{I I} e^{\frac{i L k_{I I}}{2}}\end{array}\right)$ and $M_{I}^{-1}$ is the inverse of $M_{I}$ matrix.

In a similar way, continuity of $\psi(x)$ and $\frac{d \psi}{d x}$ at $\mathrm{x}=+\mathrm{L} / 2$ gives the matrix equation as:

$$
\begin{aligned}
& M_{I I I}\left(\begin{array}{l}
C \\
D
\end{array}\right)=M_{4}\left(\begin{array}{l}
E \\
F
\end{array}\right) \\
& \left(\begin{array}{l}
C \\
D
\end{array}\right)=M^{I I}\left(\begin{array}{l}
E \\
F
\end{array}\right), \text { where } M^{I I}=M_{I I I}^{-1} M_{I V}
\end{aligned}
$$

where $M_{I I I}=\left(\begin{array}{cc}e^{\frac{i L k_{I I}}{2}} & e^{-\frac{i L k_{I I}}{2}} \\ i k_{I I} e^{\frac{i L k_{I I}}{2}} & -i k_{I I} e^{-\frac{i L k_{I I}}{2}}\end{array}\right)$ and $M_{I V}=\left(\begin{array}{cc}0 & e^{-\frac{L k_{I}}{2}} \\ 0 & -k_{I} e^{-\frac{L k_{I}}{2}}\end{array}\right)$ and $M_{I I I}^{-1}$ is the inverse of $M_{I I I}$ matrix.

Combining Eqs. 11 and 13 gives an equation of the form:

$$
\left(\begin{array}{l}
A \\
B
\end{array}\right)=M\left(\begin{array}{l}
E \\
F
\end{array}\right), M=M^{I} M^{I I}
$$

where the $2 \times 2$ matrix is the product of two matrices of Eqs. 12 and 14. Then, the transmission coefficient can be obtained from the component of transfer matrix $(\mathrm{M})$ as:

$$
T_{Q W S N R}=\left|\frac{1}{M_{12}}\right|^{2}
$$

The parameters used for the numerical simulation for $\mathrm{WS}_{2} \mathrm{NR}$ are listed in Table. 
Parameters used in the modelling of tunneling current flowing through single electron transistor

Table. with island made of $\mathrm{WS}_{2}$ nanoribbon

\begin{tabular}{|c|c|c|}
\hline Symbol & Parameters & Value [unit] \\
\hline $\mathrm{a}$ & Lattice constant & $3.153(\AA)$ \\
\hline$\theta$ & Angle between W-S bond & $0.71(\mathrm{rad})$ \\
\hline$z-m_{e}^{*}$ & Effective mass of electron (armchair nanoribbon) & $\left.0.309 \mathrm{~m}_{0}{ }^{\mathrm{a}}\right)$ \\
\hline$z-m_{e}^{*}$ & Effective mass of electron (zigzag nanoribbon) & $\left.0.412 \mathrm{~m}_{0}{ }^{\mathrm{a}}\right)$ \\
\hline $\mathrm{T}$ & Temperature & $4-300 \mathrm{~K}$ \\
\hline $\mathrm{E}_{\mathrm{g}}$ & Band gap & $1.55 \mathrm{eV}$ \\
\hline$\hbar$ & Reduced Planck's constant & $6.5821 \times 10^{-16} \mathrm{eV} . \mathrm{s}$ \\
\hline$k_{B}$ & Boltzmann constant & $8.6 \times 10^{-5} \mathrm{eV} . \mathrm{K}^{-1}$ \\
\hline
\end{tabular}

a) Electron rest mass

\section{ORCID IDs}

(D) Milan K. Bera, https://orcid.org/0000-0002-2996-890X

\section{REFERENCES}

[1] A.Lancaster, and M. Keswani, Integration, 60, 204 (2018), https://doi.org/10.1016/j.vlsi.2017.09.008.

[2] J. Gorss, (2018), https://go.nature.com/2Q4fQc5.

[3] S. Datta, Quantum Transport: Atom to Transistor (Cambridge University Press, New York, 2005).

[4] K. Goser, Nanoelectronics and Nanosystems-From Transistors to Molecular and Quantum Devices, (Springer, Berlin, Heidelberg, 2004).

[5] D. Averin, and K. Likharev, Mesoscopic phenomena in solids, 1st edn. (North-Holland, Amsterdam, 1991).

[6] T.A. Fulton, and G.J. Dolan, Phys. Rev. Lett. 59, 109 (1987), https://doi.org/10.1103/PhysRevLett.59.109.

[7] L. Zhung, L. Guo, and S.Y. Chou, Appl. Phys. Lett. 72, 1205 (1998), https://doi.org/10.1063/1.121014.

[8] C. Stampfer, E. Schurtenberger. F. Molitor, J. Güttinger, T. Ihn, and K. Ensslin, Nano Letters, 8, 2378 (2008), https://doi.org/10.1021/n1801225h.

[9] S. Manzeli, D. Ovchinnikov, D. Pasquier, O. Yazyev, and A. Kis, Nature Reviews Materials, 2, 17033 (2017), https://doi.org/10.1038/natrevmats.2017.33.

[10] M.K. Bera, R. Kharb, N. Sharma, A.K. Sharma, R. Sehrawat, S.P. Pandey, R. Mittal, and D.K. Tyagi, Journal of Electronic Materials, 48, 3504 (2019), https://doi.org/10.1007/s11664-019-07058-0.

[11] A.C Dias, F. Qu, D.L. Azevedo, and J. Fu, Phys. Rev. B, 98, 075202 (2018), https://doi.org/10.1103/PhysRevB.98.075202.

[12] N. Zettili, Quantum mechanics: concepts and applications. 2nd ed. (Wiley \& Sons, New York, 2009).

[13] S.M. Sze, and K.K. Ng, Physics of Semiconductor Devices, 3rd ed. (Wiley \& Sons, New York, 2006).

\section{КВАНТОВОМЕХАНІЧНЕ АНАЛІТИЧНЕ МОДЕЛЮВАННЯ СТРУМУ СТОКУ ОДНОЕЛЕКТРОННОГО ТРАНЗИСТОРА 3 ЗАТВОРОМ ІЗ ЗИГЗАГОПОДІБНОЇ НАНОСТРІЧКИ ДИСУЛЬФІДУ ВОЛЬФРАМУ Мілан К. Бера}

Доцент кафедри фізики Махаріші Маркандешвар (вважається університетом) Муллана, Амбала, Хар'яна, Індія

Серед багатьох нових наноелектронних пристроїв одноелектронний транзистор (SET) є однією з граничних архітектур пристроїв, яка може запропонувати високу робочу швидкість при наднизькому енергоспоживанні. Він використовує контрольоване електронне тунелювання для посилення струму і зберігає свою масштабованість навіть в атомному масштабі. Запропоновано нову архітектуру пристрою SET на основі затвору, який виконаний з одношарової зигзагоподібної нанострічки дисульфіду вольфраму $\left(\mathrm{WS}_{2} \mathrm{NR}\right)$. Аналітична модель, заснована на квантовомеханічному підході, розроблена для дослідження тунельного току стоку, що протікає через запропонований WS 2 NR SET. Iз симуляційного дослідження було помічено, що струм пристрою не протікає у області кулонівської блокади, тоді як за межами цієї області значення струму стоку поступово зменшується для довших нанострічок, ймовірно, через формування ширшого потенційного каналу у режимі затвору, що допомагає знизити швидкість тунельних електронів.

КЛЮЧОВІ СЛОВА: кулонівська блокада, нанострічка, одноелектронний транзистор, дисульфід вольфраму, тунельний струм

\section{КВАНТОВОМЕХАНИЧЕСКОЕ АНАЛИТИЧЕСКОЕ МОДЕЛИРОВАНИЕ ТОКА СТОКА ОДНОЭЛЕКТРОННОГО ТРАНЗИСТОРА С ЗАТВОРОМ ИЗ ЗИГЗАГООБРАЗНОЙ НАНОЛЕНТЫ ДИСУЛЬФИДА ВОЛЬФРАМА Милан К. Бэра}

Доцент кафедры физики Махариши Маркандешвар (считается университетом) Муллана, Амбала, Харьяна, Индия

Среди многих новых наноэлектронных устройств одноэлектронный транзистор (SET) является одной из предельных архитектур устройств, которая может предложить высокую рабочую скорость при сверхнизком энергопотреблении. Он использует контролируемое электронное туннелирование для усиления тока и сохраняет свою масштабируемость даже в атомном масштабе. Предложена новая архитектура устройства SET на основе затвора, который выполнен из однослойной зигзагообразной наноленты дисульфида вольфрама $\left(\mathrm{WS}_{2} \mathrm{NR}\right)$. Аналитическая модель, основанная на квантово-механическом подходе, разработанная для исследования туннельного тока стока, протекающего через предложенный $\mathrm{WS}_{2} \mathrm{NR}_{\mathrm{SET}} \mathrm{B}$ модельных исследования было замечено, что ток устройства не протекает в области кулоновской блокады, тогда как за пределами этой области значение тока стока постепенно уменьшается для длинных нанолент, вероятно, через формирование более широкого потенциального канала в режиме затвора, что помогает снизить скорость туннельных электронов.

КЛЮЧЕВЫЕ СЛОВА: кулоновская блокада, нанолента, одноэлектронный транзистор, дисульфид вольфрама, туннельный ток 